Eur. J. Clin. Chem. Clin. Biochem.

Vol. 31, 1993, pp. 375-380

(C) 1993 Walter de Gruyter \& Co.

Berlin - New York

\title{
Determination of Nerve Growth Factor Concentrations in Human Samples by Two-Site Immunoenzymometric Assay and Bioassay
}

\author{
By Martina Näher-Noé, H. Gnahn, A. Grundler, J. Klingelhöfer, A. Weindl and B. Conrad \\ Neurologische Klinik der Technischen Universität München, München
}

(Received July 7, 1992/February 3, 1993)

\begin{abstract}
Summary: Nerve growth factor is a neurotrophic protein which is known to act on sympathetic and sensory neurons and on the magnocellular cholinergic neurons of the basal forebrain. We quantified nerve growth factor in human tissues and body fluids by two methods, a rapid and sensitive two-site immunoenzymometric assay and a bioassay using dissociated chick dorsal root ganglion neurons. The two-site immunoenzymometric assay detects nerve growth factor in concentrations as low as $0.5-2.5 \mathrm{ng} / \mathrm{l}$. Using a monoclonal antibody to mouse nerve growth factor, we found that the signal of the antibody for recombinant human nerve growth factor is about $60-90 \%$ of the signal for mouse nerve growth factor. As a control for the specificity of our data, a bioassay for nerve growth factor was performed and the results showed a good correlation. The highest nerve growth factor concentrations were found in sciatic nerve $(2.5 \mathrm{ng} / \mathrm{g}$ wet weight), cardiac atrium muscle $(1.5 \mathrm{ng} / \mathrm{g}$ wet weight) and in the central nervous system in the hippocampus $(1.9 \mathrm{ng} / \mathrm{g}$ wet weight). Lower nerve growth factor concentrations were measured in human sera $(0.2 \mathrm{ng} / \mathrm{g}$ wet weight). No nerve growth factor was detectable in cerebrospinal fluid. The distribution of human nerve growth factor-rich tissues is similar to that reported for rat tissues.
\end{abstract}

\section{Introduction}

Nerve growth factor is a neurotrophic protein which is synthesized by target tissues of nerve growth factorsensitive neurons, selectively taken up by the nerve terminals and transported retrogradely to the cell bodies. Nerve growth factor has been shown to act on sympathetic and neural crest-derived sensory neurons in the peripheral nervous system as well as on the magnocellular cholinergic neurons of the basal forebrain (for review, see 1.c. $(1-3)$ ). It has been suggested that nerve growth factor is involved in the neuropathology of Alzheimer's disease (4). In the peripheral nervous system nerve growth factor may play a role in the development of autonomic and sensory neuropathies (5). To clarify whether nerve growth factor is of physiological or pathological significance in humans the sensitive and reliable quantification of endogenous nerve growth factor in human tissues and body fluids is a prerequisite.
The genomic sequence of human nerve growth factor has been determined (6) and small quantities of biologically active recombinant human nerve growth factor have already been produced (Genentech, USA). Since the sequence homology between murine and mature human nerve growth factor is $86 \%$ on the nucleotide level and $90 \%$ on the amino acid level (6), a relatively high immunological cross-reactivity is to be expected. Since the levels of nerve growth factor in tissues are extremely low in general, there is a need for a highly sensitive test system. The bioassay for nerve growth factor, which is based on the neurotrophic effect of nerve growth factor on embryonic sensory neurons (7), requires time-consuming cell culture procedures and is not suitable for measurements in a large number of samples. In competitive immunoradiometric assays, problems arise from the unspecific binding of nerve growth factor, for example by $\alpha_{2}$-macroglobulin $(8,9)$. A two-site immunoradiome- 
tric assay (8) yielded reliable results, but did not attain the sensitivity required for measurements in human tissues and body fluids. Two-site immunoenzymometric assays $(10,11)$ allowed a reliable and sensitive determination of nerve growth factor concentrations, but required sophisticated equipment for coating glass beads or polystyrene tubes with antibody and for fluorometric measurement of the substrate reaction. Based on the fluorometric methods described $(10,11)$, we therefore developed an assay $(12,13)$ which uses a chromogenic substrate and which is adapted to microtitre plates. We employed this method to determine nerve growth factor concentrations in human tissues, cerebrospinal fluid and serum using recombinant human nerve growth factor as a standard. Additionally, we examined the specificity of our data by determining the nerve growth factor concentrations in a sensory neuron bioassay.

\section{Materials and Methods}

Two-site immunoenzymometric assay

The immunoenzymometric assay was performed as a two-site assay using the same antibody on both sites, since nerve growth factor is a homo-dimer consisting of two identical subunits. We employed the anti mouse nerve growth factor monoclonal antibody MAB 27/21 (10). This antibody, as well as our protocol for the assay, is now available from Boehringer Mannheim, Germany. Rigid microtitre plates with high binding capacity and low variation coefficient (Immuno, Nunc) were coated with antibody protein overnight at $4{ }^{\circ} \mathrm{C}(0.3 \mathrm{mg}$ protein per litre carbonate/bicarbonate buffer $0.05 \mathrm{~mol} / \mathrm{l} ; \mathrm{pH}$ 9.7). The plates were washed with Tris buffer $(0.05 \mathrm{~mol} / 1$ Tris; $0.15 \mathrm{~mol} / 1 \mathrm{NaCl}$. $0.005 \mathrm{~mol} / 1 \mathrm{MgCl}_{2} ; 1 \mathrm{~g} / 1$ Triton-X-100; $\mathrm{pH} 7.0$ ) and incubated at $4{ }^{\circ} \mathrm{C}$ overnight with standard solutions of recombinant human nerve growth factor ( 2 samples of recombinant human nerve growth factor, lot 1 and lot 2 were obtained from Genentech, USA), mouse nerve growth factor (Boehringer Mannheim, Germany) or samples, diluted in Tris buffer supplemented with bovine serum albumin $(10 \mathrm{~g} / \mathrm{l})$. The concentration of mouse nerve growth factor in the standard solutions was monitored by determination of absorbances and by determination of the half-maximal survival in the bioassay (see below). The microtitre plates were washed again before the antibody coupled to $\beta$-galactosidase') (Boehringer Mannheim) was added (400 U/l buffer, containing $0.05 \mathrm{~mol} / \mathrm{l}$ Tris, $0.15 \mathrm{~mol} / 1 \mathrm{NaCl}, 0.005 \mathrm{~mol} / \mathrm{l}$ $\mathrm{MgCl}_{2}, 1 \mathrm{~g} / \mathrm{l}$ Triton-X-100, $10 \mathrm{~g} / \mathrm{l}$ bovine serum albumin; $\mathrm{pH}$ 7.00) and again incubated overnight at $4{ }^{\circ} \mathrm{C}$. The indicator reaction used chlorophenol red- $\beta$-galactopyranoside (Boehringer Mannheim) as a chromogenic substrate. After an incubation period of at least 1 hour, the absorbance was measured at a test wavelength of $570 \mathrm{~nm}$ and a reference wavelength of 630 $\mathrm{nm}$. We determined a standard curve in triplicate on each microtitre plate.

\section{Bioassay}

The in vitro bioassay (fig. 1) is based on the fact that neural crest-derived embryonic sensory neurons survive and extend neurites in culture in the presence of nerve growth factor,

1) Enzyme

$\beta$-galactosidase $(\beta$ - $D$-galactoside galactohydrolase EC 3.2.1.23)
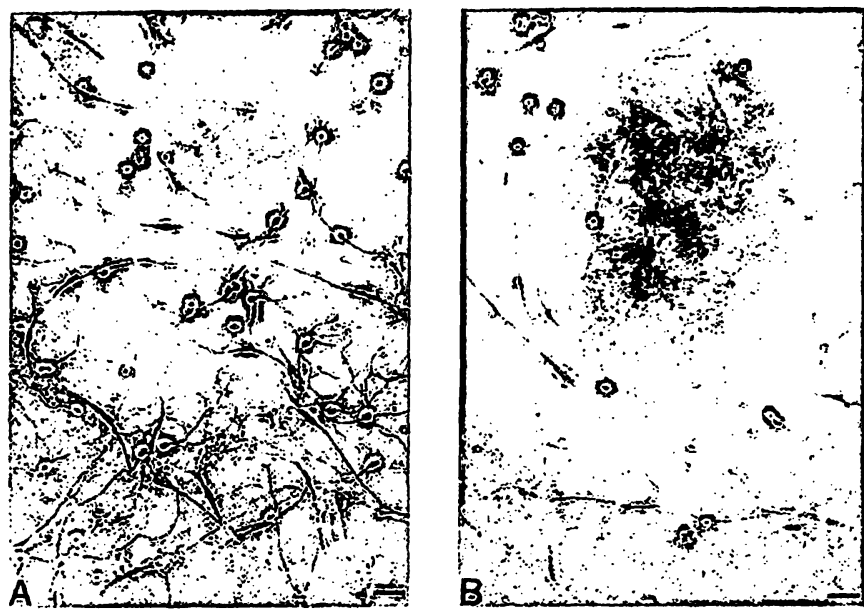

Fig. 1. Bioassay for nerve growth factor: Phase (-contrast) micrographs of dorsal root ganglia neurons cultured for $48 \mathrm{~h}$ in the presence of recombinant human nerve growth factor:

(a) $500 \mathrm{ng} / \mathrm{l}$ medium; (b) $5 \mathrm{ng} / \mathrm{l}$ medium calibration bar $=50 \mu \mathrm{m}$.

whereas they die rapidly in its absence $(7,14-16)$. Chick dorsal root ganglia (embryonic day 8) were prepared and collected in phosphate-buffered saline. The ganglia were incubated in phosphate-buffered saline containing $1 \mathrm{~g} / 1$ trypsin (Worthington) and dissociated by gentle trituration with a siliconized Pasteur pipette. The cells were then suspended in F14 medium (Gibco) supplemented with horse serum (100 ml/l medium; Gibco), preplated in $100 \mathrm{~mm}$ dishes (Nunc) in order to remove nonneuronal cells, then plated into 24-well culture dishes (Costar) coated with polyornithine $(0.5 \mathrm{~g} / 1$ in borate buffer; Sigma) and laminin (4 mg/l; a gift from $D$. Edgar). Samples, or standard dilutions of mouse nerve growth factor and recombinant human nerve growth factor in the range of $5-2000 \mathrm{ng} / \mathrm{l}$ medium were added. The rate of surviving neurons was dose-dependent at concentrations of nerve growth factor ranging from 20-500 $\mathrm{ng} / \mathrm{l}$ culture medium, mouse nerve growth factor showing equivalent activity to that of recombinant human nerve growth factor. The biological activity of both mouse nerve growth factor and recombinant human nerve growth factor was blocked by the specific anti-mouse nerve growth factor monoclonal antibody (MAB 27/21). For all measurements, the addition of MAB 27/21 (in final concentrations of $10-200 \mu \mathrm{g} / \mathrm{l}$ culture medium) to parallel samples served as a control to distinguish nerve growth factor-specific survival of the cells from effects of other uncharacterized factors. The detection limit of the nerve growth factor bioassay is in the range of $10-$ $20 \mathrm{ng} / \mathrm{l}$ cell culture medium.

\section{Preparation of tissue samples}

Human tissues were obtained from the Department of Forensic Medicine, University of Munich $4.5-20 \mathrm{~h}$ post mortem. Adult Wistar rats were killed by cervical dislocation. Bovine tissues were obtained from the municipal slaughterhouse 0.5 and $24 \mathrm{~h}$ post mortem. Tissues were frozen in liquid nitrogen and stored at $-80^{\circ} \mathrm{C}$. After homogenization at $4^{\circ} \mathrm{C}$ in Tris buffer $(0.1$ $\mathrm{mol} / \mathrm{l}$ Tris, $0.3 \mathrm{~mol} / 1 \mathrm{NaCl}, 20 \mathrm{~g} / 1$ bovine serum albumin; $\mathrm{pH}$ 7.0), containing aprotinin (20000 kallikrein units per litre), 0.1 $\mathrm{mmol} / \mathrm{l}$ benzethoniumchloride (Serva), and $1 \mathrm{mmol} / \mathrm{l}$ benzamidine, the homogenates were ultracentrifuged. For the EIA, the supernatants were diluted $1+1$ with buffer (containing 0.01 $\mathrm{mol} / \mathrm{l} \mathrm{MgCl}_{2}$ and $2 \mathrm{~g} / \mathrm{l}$. Triton-X-100; $\mathrm{pH} 7.0$ ). For the biosassay, the supernatants were diluted with F14 medium containing horse serum ( $100 \mathrm{ml} / 1$ medium; Gibco) and filtered using $2 \mu \mathrm{m}$ filters (Amicon). Unselected sera and cerebrospinal fluid samples were freshly obtained continuously from our diagnostic 
laboratory. For the bioassay, sera were incubated for 30 minutes at $51^{\circ} \mathrm{C}$ to remove cytotoxic complement activity. Final dilutions of samples ranged between $1: 10$ and $1: 20$. For all samples the recovery of nerve growth factor was determined by adding $0.05-0.5 \mathrm{pg} / 1$ recombinant human nerve growth factor to one part of the homogenate before the homogenates were ultracentrifuged and by calculating the fraction of recovered nerve growth factor. False positive results in a two-site assay might be found when anti-mouse IgG present in a sample "crosslinks" the first and second monoclonal antibody. We ruled out this possibility by incubating samples and standards with unspecific monoclonal antibodies (Blockierungsreagenz CK 33, available on request from Boehringer Mannheim) in different concentrations from $0.6-42 \mathrm{mg} / \mathrm{l}$ in order to bind anti-mouse IgG.

\section{Results}

An immunoenzymometric assay for nerve growth factor based on a chromogenic detection system using $\beta$-galactosidase and chlorophenol red- $\beta$-galacotopyranoside was developed. In order to adapt the assay to microtitre plates, different types of plates including vinyl, polystyrene and activated polystyrene plates were compared, and activated polystyrene plates were selected for highest binding capacity. Coating concentrations for the nerve growth factor antibody and nerve growth factor antibody- $\beta$-galcatosidase conjugate were optimized. For blocking the plates after antibody adsorption, buffers containing bovine serum albumin, horse serum, rat serum and ovalbumin were compared, and it was found that bovine serum albumin in a concentration of $10 \mathrm{~g} / 1$ yielded the best blocking results. For the incubation step with nerve growth factor, different buffer, $\mathrm{pH}$ and detergent conditions were tested; it was found that coating at $\mathrm{pH}$ 9.7 and incubation at $\mathrm{pH} 7.0$ using the detergent Triton-X-100 gave the best results.

Furthermore, all incubation steps were performed with various combinations of the following incubation conditions: incubation at $4{ }^{\circ} \mathrm{C}$ overnight, at room temperature for two hours, or at $37^{\circ} \mathrm{C}$ for two hours. All of these variations yielded standard curves, but for all incubation steps, incubation at $4^{\circ} \mathrm{C}$ overnight yielded the lowest and incubation at $37^{\circ} \mathrm{C}$ for two hours yielded the highest standard deviations for the triplicate measurements. We therefore decided to perform all measurements with human nerve growth factor by incubating at $4{ }^{\circ} \mathrm{C}$ overnight, since in human tissues relatively low nerve growth factor concentrations near the detection limit of the assay were expected. Nevertheless, it is possible to perform the assay by incubating for two hours at room temperature and thus achieve good results in the medium range of sensitivity within.

Under these optimized assay conditions the detection limit of the nerve growth factor assay was $0.5 \mathrm{ng} / \mathrm{l}$ (the detection limit was defined as three standard deviations of the blank signal). Figure 2 shows a typical standard curve. When the more rapid assay protocol with incubation at room temperature was used, the detection limit was $2.5 \mathrm{ng} / \mathrm{l}$. The intra-assay variance of the optimized assay was determined by assaying a sample 18 times on one microtitre plate. The inter-assay variance was estimated by analysis of 4 different samples in 18 consecutive runs. The reproducibility is given in table 1 . To examine the specificity of the assay, insulin and lysozyme were tested as antigens. Neither of these gave a signal. When comparing mouse nerve growth factor and recombinant human nerve growth factor, the signal for recombinant human nerve growth factor was about $60 \%$ of the signal for the same concentration of mouse nerve growth factor in lot 1 of human nerve growth factor and $90 \%$ of the signal of mouse nerve growth factor in lot 2 of human nerve growth factor. To find out

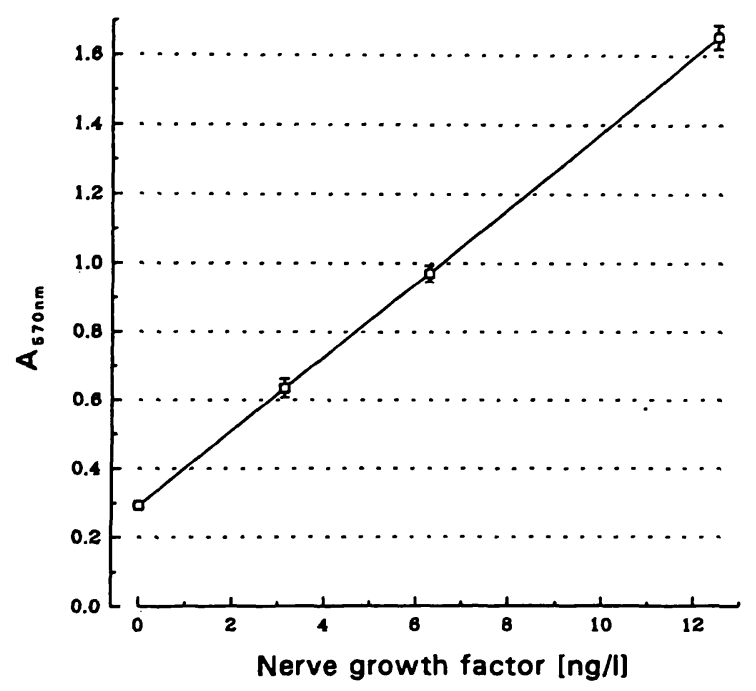

Fig. 2. Typical standard curve of the enzyme immunoassay for nerve growth factor for measurements in the lower range of sensitivity.

Tab. 1. Nerve growth factor assay precision

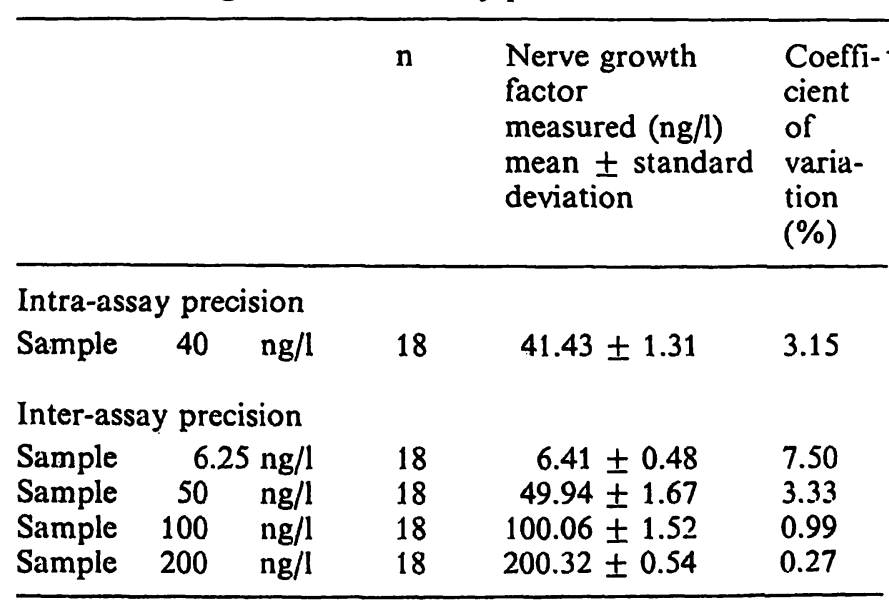




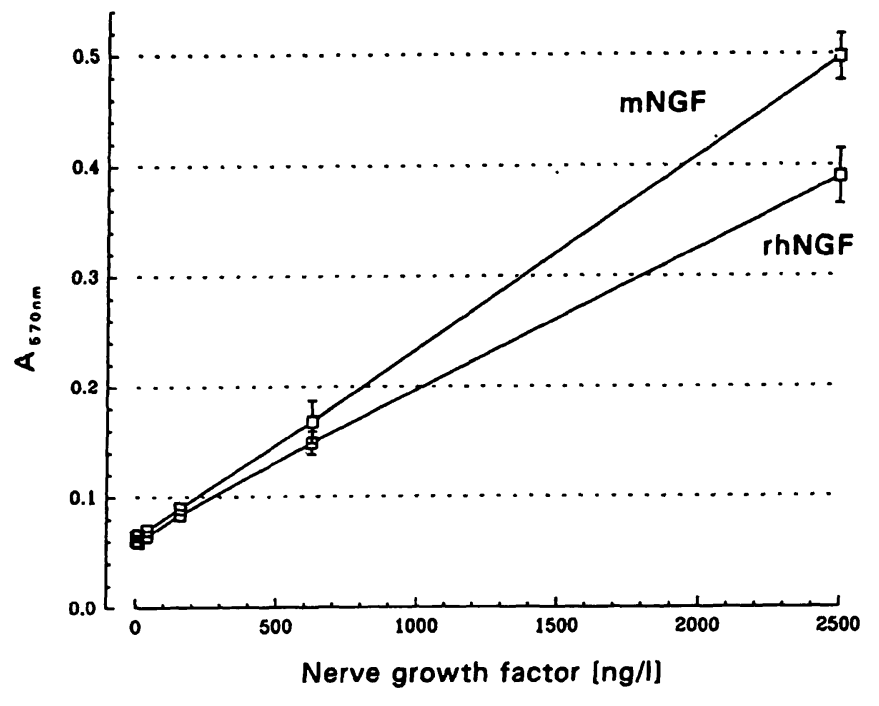

Fig. 3. Comparison of standard curves for mouse nerve growth factor (mNGF) and recombinant human nerve growth factor (rhNGF) from lot 2. The data for the two graphs were determined on the same microtitre plate.

whether this difference is due to different concentrations of recombinant human nerve growth factor in the two samples received, we tried to further evaluate the nerve growth factor concentration in the samples by bioassay and measurement of optical density, but the amount of recombinant human nerve growth factor we could obtain from the two lots was so small that these experiments were not possible. Figure 3 shows a comparison of the standard curves of mouse nerve growth factor and recombinant human nerve growth factor from lot 1.

For testing samples in the bioassay it is necessary to remove cytotoxic complement activity by incubating the samples for 30 minutes at $51^{\circ} \mathrm{C}$. In order to find out whether this incubation leads to a degradation of nerve growth factor we assayed samples before and after incubation in the immunoenzymometric assay. There was a decrease of $14 \%$ in the nerve growth factor concentration in tissue homogenates and of $22 \%$ in serum samples. This decrease was compensated for in each sample by the calculation of the recovery of nerve growth factor, which was exogenously added before the incubation step (as described in the section, preparation of tissue samples). In order to quantify a possible decrease of nerve growth factor in post mortem tissues, we determined the nerve growth factor concentrations in rat heart, sciatic nerve, hippocampus and the rest of the brain immediately post mortem and 6 and 24 hours post mortem and in bovine hippocampus, temporal cortex, occipital cortex and spinal cord 0.5 and 24 hours post mortem. When preparing the tissue samples, it was noted that rat brain tissues 6 and 24 hours post mortem already showed macroscopic colliquative changes, whereas rat heart, bovine tissues and human post mortem tissues appeared macroscopically intact. In bovine tissues and rat heart tissues no relevant decrease in nerve growth factor content was found. The mean nerve growth factor levels in rat nervous tissues 6 hours post mortem were $21 \%$ lower than immediately post mortem; 24 hours post mortem nerve growth factor levels had decreased by $37 \%$. Nerve growth factor determinations in rat heart 0,6 and 24 hours post mortem, bovine brain tissues 0.5 and 24 hours post mortem and human tissues 4.5 and 20 hours post mortem showed no relevant differences in nerve growth factor content related to the period post mortem.

Nerve growth factor concentrations were determined in various human post mortem tissues. The recovery of exogenously added recombinant human nerve growth factor was in the range of 70 to $100 \%$. Nerve growth factor measurements in human heart atrium muscle, skeletal muscle, sciatic nerve, temporal cortex, hippocampus, and cerebellum were performed by the immunoenzymometric assay and the bioassay in parallel. Relatively high nerve growth factor concentrations were found in sciatic nerve and cardiac atrium muscle. In the central nervous system, the highest nerve growth factor concentrations were measured in the hippocampus (tab. 2).

When parallel measurements using immunoenzymometric assay and bioassay were performed in human sera and cerebrospinal fluid samples, the recovery of exogenously added recombinant human nerve growth

Tab. 2. Nerve growth factor concentrations in human tissues and body fluids

\begin{tabular}{lll}
\hline & $\begin{array}{l}\text { Immuno- } \\
\text { enzymometric } \\
\text { assay } \\
\text { nerve growth } \\
\text { factor ng/1 } \\
\text { wet weight }\end{array}$ & $\begin{array}{l}\text { Bioassay } \\
\text { nerve growth } \\
\text { factor ng/g } \\
\text { wet weight }\end{array}$ \\
& $1.5 \pm 0.4$ & $0.8 \pm 0.5$ \\
\hline Cardiac atrium muscle & $0.3 \pm 0.01$ & not detectable \\
Skeletal muscle & $2.4 \pm 0.5$ & $2.6 \pm 0.5$ \\
Sciatic nerve & $1.2 \pm 0.02$ & $1.5 \pm 0.5$ \\
Temporal cortex & $1.9 \pm 0.3$ & $2.0 \pm 0.5$ \\
Hippocampus & $0.9 \pm 0.2$ & $0.5 \pm 0.5$ \\
Cerebellum & not detectable & not detectable \\
Cerebrospinal fluid & $(\mathrm{n}=92)$ & $(\mathrm{n}=5)$ \\
Serum & $0.2 \pm 0.02$ & $0.17 \pm 0.01$ \\
& $(\mathrm{n}=30)$ & $(\mathrm{n}=29)$ \\
\hline
\end{tabular}

Values given are means \pm standard deviation. For tissues, five independent experiments (involving samples from 5 different individuals) were performed, each involving triplicate determinations. For body fluids, the number of independent experiments ( $n$ ) is given in parenthesis; each experiment was performed in triplicate. 
factor was 50 to $110 \%$. Nerve growth factor concentrations were in the range of $200 \mathrm{ng} / \mathrm{l}$ in serum. No nerve growth factor was detectable in cerebrospinal fluid (tab. 2). Since the body fluids were diluted by a factor of $1: 10$ for the assays, the limit of nerve growth factor detection was about $20 \mathrm{ng} / \mathrm{l}$ sample in the EIA and $150 \mathrm{ng} / 1$ sample in the bioassay.

\section{Discussion}

We optimized an immunoenzymometric assay to permit the detection of nerve growth factor in concentrations as low as 0.5 to $2.5 \mathrm{ng} / \mathrm{l}$. The assay can be carried out in microtitre plates and this permits rapid handling of a large number of samples. Since the indicator reaction uses a chromogenic substrate, it can be followed photometrically and there is no need for sophisticated equipment. The signal for recombinant human nerve growth factor in the assay varied in the range of 60 to $90 \%$ of the signal for mouse nerve growth factor in different lots of recombinant human nerve growth factor. This affinity and sensitivity should be sufficient for sensitive quantification of human nerve growth factor, since the nerve growth factor concentrations reported, for example in rat tissues, are in the range of $0.1-1.0 \mathrm{ng} / \mathrm{g}$ wet weight $(10,17)$. To examine the specificity, insulin, which shows partial sequence homologies with nerve growth factor (6), and lysozyme, which is a strongly basic protein like nerve growth factor, were tested and gave no signal in the assay. When we measured nerve growth factor in rat, bovine and human tissues at different times in the first 24 hours post mortem, we found no relevant decrease in nerve growth factor content, except in rat brain tissues, where the decrease is probably due to the pronounced colliquative changes.

We quantified nerve growth factor in human tissues and body fluids by two different methods; the immunoenzymometric assay and a nerve growth factor bioassay using dissociated chick sensory neurons. The nerve growth factor bioassay serves as a control for the specificity of the EIA, since the signal depends on the binding of nerve growth factor to its receptor on cells in culture; the receptor binding site of the nerve growth factor molecule has been highly conserved during the evolution of vertebrates (7). We found comparable results for the immunoenzymometric assay and bioassay measurements.

The highest nerve growth factor concentrations were found in sciatic nerve, which contains sensory fibres, and in heart atrium muscle, which is sympathetically innervated. In the central nervous system the highest nerve growth factor levels were measured in hippocampus and cortex, which are target tissues of the magnocellular cholinergic system of the basal forebrain. This means that the nerve growth factor concentration correlates with the physiological distribution of nerve growth factor-sensitive neurons and their target tissues. The observed distribution of nerve growth factor-rich tissues is similar to that reported for rat tissues $(10,17)$, which was also confirmed by our immunoenzymometric assay.

In comparison with nerve growth factor levels in tissues containing nerve growth factor-sensitive neurons, relatively low nerve growth factor concentrations in the range of $200 \mathrm{ng} / \mathrm{l}$ were measured in human sera, while the signal was not detectable in cerebrospinal fluid samples. In early studies using one-site immunoradiometric assay, much higher nerve growth factor levels were detected in mouse sera, but these results could not be confirmed by bioassay or twosite immunoradiometric assay (8). Bioassay and twosite immunoradiometric assay measurements are limited by the sensitivity of these assays, but they showed that the nerve growth factor concentration was lower than $5000 \mathrm{ng} / \mathrm{l}$ by the two-site immunoradiometric assay and lower than $2000 \mathrm{ng} / \mathrm{l}$ serum by the dorsal root ganglion bioassay (8). Beck et al. (18), using a more sensitive two-site immunoradiometric assay, found that the nerve growth factor levels in human serum are lower than $500 \mathrm{ng} / \mathrm{l}$. Stephani et al. (19) evaluated serum nerve growth factor levels with a sensory neuron bioassay, and reported concentrations of 200 to $1000 \mathrm{ng} / \mathrm{l}$, in the same range as our results. These low but measurable nerve growth factor levels in human body fluids indicate that the primary function of nerve growth factor is a local trophic effect, but do not exclude an additional systemic effect.

To determine whether nerve growth factor has a pathological or physiological significance in humans, nerve growth factor concentrations can now be determined in a relatively large number of human sera, cerebrospinal fluid samples and post mortem tissues and. correlated with the clinical data. Monoclonal antibodies against human nerve growth factor should be developed as soon as suitable quantities of recombinant human nerve growth factor are available.

\section{Acknowledgement}

The authors would like to thank Dr. Hans Thoenen for kindly providing research facilities. We are grateful to $I$. Gebhard for technical assistance. The project was supported by Boehringer Mannheim, Mannheim, Germany and Fidia Inc.. Italy. 


\section{References}

1. Levi-Montalcini, R., Meyer, H. \& Hamburger, V. (1954) In vitro experiments on the effects of mouse sarcomas 180 and 37 on the spinal and sympathetic ganglia of the chick embryo. Cancer Res. 14, 49-57.

2. Greene, L. A. \& Shooter, E. M. (1980) The nerve growth factor: Biochemistry, synthesis and mechanism of action. Ann. Rev. Neurosci. 3, 353-402.

3. Thoenen, H., Bandtlow, C. \& Heumann, R. (1987) The physiological function of nerve growth factor in the central nervous system: Comparison with the periphery. Rev. Physiol. Biochem. Pharmacol. 109, 145-178.

4. Hefti, F. \& Weiner, W. J. (1986) Nerve growth factor and Alzheimer's disease. Ann. Neurol. 20, 275-281.

5. Anand, P., Rudge, P., Mathias, C. J., Springall, D. R., Ghatei, M. A., Näher-Noé, M., Sharief, M., Misra, R. P., Polak, J. M., Bloom, S. R. \& Thomas, P. K. (1991) New autonomic and sensory neuropathy with loss of adrenergic sympathetic and sensory neuropeptides. Lancet $337,1253-$ 1254.

6. Ullrich, A.. Gray, A., Berman, C. \& Dull, T. J. (1983) Human $\beta$-nerve growth factor gene sequence highly homologous to that of mouse. Nature $303,821-825$.

7. Levi-Montalcini, R. (1987) The nerve growth factor: Thirty years later. EMBO J. 6, 1145-1154.

8. Suda, K., Barde, Y.-A. \& Thoenen, H. (1978) Nerve growth factor in mouse and rat serum: Correlation between bioassay and radioimmunoassay determination. Proc. Natl. Acad. Sci. USA 75, 4042-4046.

9. Ronne, H., Anundi, H., Rask, L. \& Peterson, P. A. (1979) Nerve growth factor binds to serum alpha-2-macroglobulin. Biochem. Biophys. Res. Commun. 87, 330-336.

10. Korsching, S. \& Thoenen, H. (1983) Nerve growth factor in sympathetic ganglia and corresponsing target organs of the rat: Correlation with density of sympathetic innervation. Proc. Natl. Acad. Sci. USA 80, 3513-3516.

11. Furukawa, S., Kamo, I., Furukawa, Y., Akazawa, S., Satoyoshi, E., Itoh, K. \& Hayashi, K. (1983) A highly sensitive enzyme immunoassay for mouse $\beta$ nerve growth factor. J. Neurochem. 40, 734-744.
12. Grundler, A., Näher-Noé, M. \& Gnahn, H. (1989) Towards Quantification of nerve growth factor in human tissues and body fluids. In: Clinical Pharmacology 2: Pharmacological Interventions on Central Cholinèrgic Mechanisms in Senile Dementia (Alzheimer's Disease) (Kewitz, H., Bickel, U. \& Thomsen, T., eds.) pp. 185-186. Zuckschwerdt Verlag, München.

13. Spranger, M., Lindholm, D., Bandtlow, C., Heumann, R., Gnahn, H., Näher-Noé, M. \& Thoenen, H. (1990) Regulation of nerve growth factor (NGF) synthesis in the rat central nervous system: Comparison between the effects of interleukin-1 and various growth factors in astrocyte cultures and in vivo. Eur. J. Neurosci. 2, 69-76.

14. Levi-Montalcini, R. \& Angeletti, P. U. (1963) Essential role of the nerve growth factor on the survival and maintenance of dissociated sensory and sympathetic neurons in vitro. Dev. Biol. 7, 653-659.

15. Barde, Y.-A., Edgar, D. \& Thoenen, H. (1982) Culture of embryonic chick dorsal root and sympathetic ganglia. In: Neuroscience Approached through Cell Culture, Vol I (P̈feiffer, S., ed.), pp. 83-86. CRC, New York.

16. Davies, A. M. (1989) Neurotrophic factor bioassay using dissociated neurons. In: Nerve Growth Factors, IBROHandbook series, Vol 12 (Rush, R. A., ed.), pp. 81 -94. J. Wiley \& Sons Ltd., New York.

17. Korsching, A., Auburger, G., Heumann, R., Scott, J. \& Thoenen, H. (1985) Levels or nerve growth factor and its mRNA in the central nervous system of the rat correlate with cholinergic innervation. EMBO J. 4, 1389-1393.

18. Beck, C. E. \& Perez-Polo, J. (1982) Human $\beta$-nerve growth factor does not crossreact with antibodies to mouse $\beta$-nerve growth factor in a two site radioimmunoassay. J. Neurosci. Res. 8, 137-152.

19. Stephani, U., Sutter, A. \& Zimmermann, A. (1987) Nerve growth factor (NGF) in serum: Evaluation of serum NGF levels with a sensitive bioassay employing embryonic sensory neurons. J. Neurosci. Res. 17, 25-35.

\author{
Dr. med. M. Näher-Noé \\ Dept. of Neurology \\ Technical University of Munich \\ Möhlstraße 28 \\ W-8000 München 80 \\ Bundesrepublik Deutschland
}

